\title{
Faktor-Faktor Penyebab Keterlambatan Pengklaiman BPJS Rawat Inap Di Rumah Sakit Umum Imelda Pekerja Indonesia (RSU IPI) Medan Tahun 2020
}

\author{
Erlindai \\ Program Studi D-III Perekam dan Informasi Kesehatan, Universitas Imelda Medan
}

\section{Article Info}

\section{Article history:}

Received July 27, 2020

Revised August 29, 2020

Accepted August 29, 2020

\section{Keywords:}

Form Design

Kidney

Report

Rasyida Hospital

\begin{abstract}
The Social Security Organizing Agency (BPJS) is an institution formed to organize a Social Security Program in Indonesia based on Law Number 40 of 2004 and Law Number 24 of 2011. Indonesian General Imelda Worker Hospital is a private hospital in the city of Medan who have collaborated with BPJS Based on the initial survey of researchers on 30 medical records documents 13 files $(43 \%)$ are in accordance with claim requirements and 17 files (56\%) are incomplete. Data collection in this study is a questionnaire method. This research was conducted using quantitative research methods with cross sectional approach. The population used in this study were all medical record officers in the medical record unit in the IPI General Hospital Medan as many as 31 officers. Based on the results of a statistical test research conducted using the Chi Square (X2) computer test application with a significance of $95 \%(\mathrm{p}<0.05)$ it can be concluded that the Hospital conducts an evaluation for medical records officers so that the performance of officers is as expected. Increase evaluation for the completeness of medical record documents used in BPJS claims.
\end{abstract}

This is an open access article under the CC BY-SAlicense.

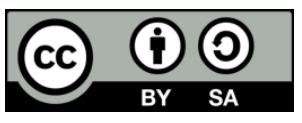

\section{Corresponding Author:}

Erlindai,

Program Studi D-III Perekam dan Informasi Kesehatan,

Universitas Imelda Medan,

Jl. Bilal No. 52 Kelurahan Pulo Brayan Darat I Kecamatan Medan Timur, Medan - Sumatera Utara.

Email: erlindaipurba@mail.com

\section{PENDAHULUAN}

Permenkes 3 Tahun 2020 Tentang klasifikasi dan Perizinan Rumah Sakit menyebutkan bahwa Rumah Sakit menyebutkan Rumah Sakit adalah institusi pelayanan kesehatan yang menyelenggarakan pelayanan kesehatan perorangan secara paripurna yang menyediakan pelayanan rawat inap, rawat jalan dan gawat darurat. Peraturan Menteri Kesehatan Nomor 3 Tahun 2020 Tentang Klasifikasi dan Perizinan Rumah Sakit ditetapkan oleh Menkes Terawan Agus putranto di Jakarta pada Tanggal 14 Januari 2020. Peraturan Menteri Kesehatan Nomor 3 Tahun 2020 Tentang Klasifikasi dan Perizinan Perundang-Undangan Kemenkumham Widodo Ekatjahjana pada tanggal 16 Januari 2020 di Jakarta. 
Menurut KMK No. 312 Tahun 2020 Standart Profesi Perekam Medis dan Informasi Kesehatan Rekam medis adalah sumber informasi dan memerlukan pengelolahan yang profesional untuk memenuhi kebutuhan berbagai aspek seperti : administrasi, hukum, keuangan, penelitian, pendidikan, pendokumentasian dan kesehatan masyarakat. Dalam pengolahan data rekam medis menghasilkan informasi kesehatan primer dan sekunder, menyajikan dan mendiseminasi informasi yang berguna untuk perencanaan dan pengambilan keputusan.

Menurut Peraturan Badan Penyelenggaraan Jaminan Sosial Kesehatan Nomor 7 Tahun 2020 pasal 2 BPJS Kesehatan membayarkan manfaat jaminan pelayanan kesehatan kepada Fasilitas Kesehatan yang bekerjasama dengan BPJS Kesehatan yang meliputi pembayaran manfaat jaminan pelayanan kesehatan di FKTP dan FKRTL.

Dalam pelaksanaan jaminan kesehatan, klaim pembayaran tidak dibayarkan oleh pemerintah, tetapi diserahkan pada pihak BPJS Kesehatan. Dokumen klaim akan diverifikasi oleh verifikator BPJS Kesehatan. Apabila pihak verifikator BPJS Kesehatan menyetujui maka klaim akan diganti oleh pihak BPJS Kesehatan, jika tidak disetujui maka klaim akan dikembalikan ke pihak rumah sakit. (Leonard, 2016)

Fasilitas Kesehatan mengajukan klaim setiap bulan secara reguler paling lambat tanggal 10 bulan berikutnya, kecuali kapitasi, tidak perlu diajukan klaim oleh Fasilitas Kesehatan. 2. BPJS Kesehatan wajib membayar Fasiltas Kesehatan atas pelayanan yang diberikan kepada peserta paling lambat 15 (lima belas) hari kerja sejak dokumen klaim diterima lengkap di Kantor Cabang/Kantor Operasional Kabupaten/Kota BPJS Kesehatan (Panduan Praktis Administrasi Klaim Fasilitas Kesehatan BPJS Kesehatan).

RSUP Dr. M. Djamil Padang, permasalahan klaim yang terjadi karena diagnosis pasien diisi oleh Program Pendidikan Dokter Spesialis (PPDS) yang memiliki pemahaman dan pengetahuan yang masih kurang tentang pengisian The Internasional Statistical Classification of Diseases and Related Helath Problem (ICD) 10 dan ICD 9 Clinical Modification (CM) sesuai kaidah, masih kurangnya keterampilan Sumber Daya Manusia (SDM) coding grouping karena masih kurangnya pelatihan serta masih ada penempatan SDM yang belum sesuai kompetensi. Belum Bridging antara aplikasi Indonesia Case Base Groups (INA CBGs), Sistem Rumah Sakit (SIM RS) dan BPJS dengan Information and Technology (IT) yang belum mendukung (Leonard, 2016).

Berdasarkan penelitian yang dilakukan oleh Puri Feriawati, Agus Perrry Kusuma tentang "faktor-faktor keterlambatan pengklaiman BPJS di rumah sakit Bayangkara Semarang Pada Tahun 2015" menemukan adanya berkas DRM (Dokumen Rekam Medis) yang tidak lengkap seperti tidak adanya tanda tangan dan nama terang dokter, diagnosis belum diisi / kode diagnosis belum diisi, riwayat perjalanan penyakit belum terisi dengan lengkap. Hal ini akan dapat menyebabkan terhambatnya proses pengajuan klaim kepada BPJS.

Berdasarkan penelitian Ilkham, Alqafi tentang "Faktor-faktor yang mempengaruhi Klaim BPJS DI Rumah Sakit Santa Maria Pemalang pada bulan Januari-September pada tahun 2017 terdapat 18,27\% dokumen rawat inap yang terlambat diklaim, pengklaiman ditolak karena ada syarat-syarat klaim yang belum dilengkap seperti lembar Resume Medis dan syarat-syarat klaim seperti KTP, KK, dan SEP. Hal ini berdampak pada keterlambatan pada proses pengajuan klaim Rumah Sakit ke pihak BPJS.

Rumah sakit Umum Imelda Pekerja Indonesia adalah salah satu Rumah Sakit swasta di Kota Medan yang sudah bekerja sama dengan BPJS. Pengajuan klaim kepada BPJS di RSU IPI Medan diajukan pada awal bulan yaitu tanggal 3 terkecuali tanggal merah atau hari libur maka akan diajukan pada hari kerja. Namun, berdasarkan wawancara dengan petugas dibagian klaim masih ditemukan adanya kendala dalam pengklaiman yaitu aplikasi dan jaringan internet yang bermasalah pada saat verifikasi sehingga menyebabkan tertundanya pekerjaan petugas, petugas coding yang belum memahami tentang coding 
grouping dan ketidaklengkapan persyaratan klaim. Berdasarkan survei awal peneliti pada 30 dokumen rekam medis 13 berkas (43\%) sudah sesuai dengan persyaratan klaim dan 17 berkas $(56 \%)$ belum lengkap, ketidaklengkapan diantaranya masih terdapat resume yang belum ditandatangani dokter, belum lengkapnya format pasien pulang, belum terisinya pemeriksaan penunjang serta kelengkapan adminstrasi seperti fotokopi KTP, kartu keluarga, serta fotokopi kartu BPJS pasien.

Berdasarkan latar belakang yang telah diuraikan diatas maka rumusan masalah yang diambil penelitian ini adalah apa saja faktor yang menyebabkan keterlambatan pengklaiman BPJS di Rumah Sakit IPI Medan.

\section{METODE PENELITIAN}

\section{A. Jenis Penelitian}

Jenis penelitian ini dilakukan dengan menggunakan metode penelitian kuantitatif dengan pendekatan Cross Sectional. Penelitian kuantitatif merupakan suatu metode penelitian yang bersifat induktif, objektif dan ilmiah dimana data yang diperoleh berupa angka-angka atau score, nilai atau pertanyaan-pertanyaan yang dinilai, dan dianalisis dengan analisis statistic (Notoadmojo, 2012). Jenis penelitian ini untuk mengetahui faktor-faktor penyebab keterlambatan pengklaiman BPJS di RSU IPI Medan.

Penelitian ini dilakukan pada bulan febuari - Juli 2020 di Rumah Sakit Umum Imelda Pekerja Indonesia (RSU IPI) Medan yang beralamat di Jl. Bilal No. 24 Pulo Brayan Darat I Medan. Penelitian ini dilakukan di Rumah Sakit Umum Imelda Pekerja Indonesia (RSU IPI) Medan yang beralamat di Jl. Bilal No. 24 Pulo Brayan Darat I Medan.

B. Populasi dan Sampel

Populasi merupakan keseluruhan objek penelitian atau objek yang diteliti (Notoadmojo, 2012). Populasi yang digunakan dalam penelitian ini adalah seluruh petugas rekam medis yang ada di unit rekam medis yang ada di RSU IPI Medan yaitu sebanyak 31 orang petugas.

Sampel adalah sebagian wakil populasi yang diteliti (Saryono, 2013). Sampel yang digunakan dalam penelitian ini adalah seluruh populasi, yaitu 10 orang petugas klaim yaitu, 4 orang petugas koder, 4 petugas administrasi dan 2 orang petugas verifikasi klaim.

C. Teknik Sampeling

Metode sampling yang digunakan untuk objek penelitian adalah 1 formulir laporan operasi yang terdapat dalam kumpulan berkas rekam medis adalah purposive sampling, teknik purposive sampling merupakan teknik pengambilan sampel sumber data dengan pertimbangan tertentu yang telah diketahui sebelumnya. Pada teknik ini penulis akan mengidentifikasi semua karakteristik populasi, misalnya dengan mengadakan studi pendahuluan atau dengan mempelajari berbagai hal yang berhubungan dengan populasi. Kemudian penulis menetapkan berdasarkan pertimbangannya, sebagian dari populasi menjadi sampel penelitian sehingga teknik pengambilan sampel secara purposive ini didasarkan pada pertimbangan pribadi penulis sendiri (Notoadmodjo, 2012).

D. Defenisi Operasional

Untuk membatasi ruang lingkup atau pengertian variabel-variabel tersebut diberi batasan atau defenisi operasional (Notoadmojo, 2012).

Adapun defenisi operasional dalam penelitian ini sebagai berikut: 
Tabel 1. Defenisi Operasional

\begin{tabular}{|c|c|c|c|c|c|c|}
\hline No & Variabel & Defenisi Operasional & $\begin{array}{l}\text { Skala } \\
\text { Ukur }\end{array}$ & Indikator & $\begin{array}{l}\text { Nilai } \\
\text { Ukur }\end{array}$ & Hasil Ukur \\
\hline 1. & $\begin{array}{l}\text { Karakteristik } \\
\text { dan } \\
\text { Pengetahuan }\end{array}$ & $\begin{array}{l}\text { Karakteristik } \\
\text { mencakup usia jenis } \\
\text { kelamin, masa kerja, } \\
\text { tingkat pendidikan }\end{array}$ & & & & \\
\hline a. & Umur & $\begin{array}{lr}\text { Lama } & \text { hidup } \\
\text { seseorang } & \text { dihitung } \\
\text { sejak lahir } & \text { hingga } \\
\text { batas } & \text { terakhir } \\
\text { hidupnya } & \\
\end{array}$ & Rasio & & & $\begin{array}{l}1.20-30 \\
\text { tahun } \\
2.31-40 \\
\text { tahun }\end{array}$ \\
\hline b. & $\begin{array}{l}\text { Jenis } \\
\text { kelamin }\end{array}$ & $\begin{array}{ll}\text { Perbedaan } & \text { bentuk } \\
\text { sifat dan fungsi } \\
\text { biologis }\end{array}$ & Nominal & & & $\begin{array}{l}\text { 1.Perempuan } \\
\text { 2. Laki-laki }\end{array}$ \\
\hline c. & pengetahuan & $\begin{array}{l}\text { Hasil pemahaman } \\
\text { petugas } \\
\text { informasi yang telah } \\
\text { didapat dari orang } \\
\text { lain. }\end{array}$ & ordinal & 10 soal & $\begin{array}{l}0-3 \\
4-6 \\
7-10\end{array}$ & $\begin{array}{l}\text { 1. kurang } \\
\text { 2. cukup } \\
\text { 3. baik }\end{array}$ \\
\hline d. & Pelatihan & $\begin{array}{l}\text { Pembelajaran tentang } \\
\text { pekerjaan yang } \\
\text { berkaitan dengan } \\
\text { pengetahuan } \\
\text { keahlian dan perilaku }\end{array}$ & Nominal & & & $\begin{array}{l}\text { 1. ada } \\
\text { 2. tidak ada }\end{array}$ \\
\hline e. & Pendidikan & $\begin{array}{lr}\text { Jenjang } & \text { pendidikan } \\
\text { formal } & \text { Yang } \\
\text { ditempuh } & \text { seseorang }\end{array}$ & ordinal & & & $\begin{array}{l}\text { 1. D3 RMIK } \\
\text { 2. S1 RMIK } \\
\text { 3. D3 Non } \\
\text { RMIK }\end{array}$ \\
\hline f. & $\begin{array}{l}\text { Pengalaman } \\
\text { kerja }\end{array}$ & \begin{tabular}{lr}
\multicolumn{2}{l}{ Proses pembentukan } \\
pengetahuan & atau \\
keterampilan & tentang \\
metode & suatu \\
pekerjaan & karena \\
keterlibatan & \\
seseorang & dalam \\
pelaksanaan & tugas \\
pekerjaan & \\
\end{tabular} & Rasio & & & $\begin{array}{l}\text { 1. 0-1tahun } \\
\text { 2. 2-3tahun } \\
\text { 3. 4-5tahun } \\
\text { 4. >5tahun }\end{array}$ \\
\hline g. & Sikap & $\begin{array}{lr}\text { Respon } & \text { Petugas } \\
\text { rekam medis } & \text { map pentingnya } \\
\text { terhadap } & \text { pengetahuan } \\
\text { menerapkan } & \\
\text { informasi } & \text { dalam } \\
\text { klaim BPS } & \\
\end{array}$ & Ordinal & 10 soal & $\begin{array}{l}10-20 \\
21-30 \\
31-40\end{array}$ & $\begin{array}{l}\text { 1. Kurang } \\
\text { 2. Cukup } \\
\text { 3. Baik }\end{array}$ \\
\hline 2. & $\begin{array}{l}\text { Sarana dan } \\
\text { Prasarana }\end{array}$ & $\begin{array}{l}\text { Alat yang digunakan } \\
\text { dalam pengolahan } \\
\text { klaim BPJS }\end{array}$ & ordinal & & & $\begin{array}{l}\text { 1. Lengkap } \\
\text { 2. Tidak } \\
\quad \text { Lengkap }\end{array}$ \\
\hline
\end{tabular}




\begin{tabular}{|c|c|c|}
\hline 3. Informasi & $\begin{array}{lrr}\text { Rekam } & \text { medis } & \text { ordinal } \\
\text { sebagai } & \text { sarana } & \\
\text { informasi } & \text { yang terisi } & \\
\text { lengkap r sesuai } & \\
\text { persyaratan klaim } & \end{array}$ & $\begin{array}{l}\text { 1.Lengkap } \\
\text { 2.Tidak } \\
\text { Lengkap }\end{array}$ \\
\hline $\begin{array}{l}\text { 4. Prosedur } \\
\text { Klaim }\end{array}$ & $\begin{array}{l}\text { Proses pengumpulan } \text { Ordinal } \\
\text { berkas BPJS sebagai } \\
\text { syarat dalam klaim }\end{array}$ & $\begin{array}{l}\text { 1. Ada } \\
\text { 2. Tidak } \\
\text { Ada }\end{array}$ \\
\hline
\end{tabular}

E. Instrumen Penelitian

Peneliti mengumpulkan data dengan menggunakan angket dengan jumlah pertanyaan sebanyak 10 item. Angket yang digunakan adalah angket tertutup, yaitu angket yang sudah dilengkapi dengan jawaban. Setiap item terdiri dari dua pilihan jawaban menurut skala Guttman. Untuk jawaban yang diberi kode 1 dan jawaban tidak adalah 0 . Skor tertinggi adalah 10 (10x1) dan yang terendah 0 (10x0) sehingga rentang skor untuk pengetahuan petugas rekam medis 0-10. Kategori tingkat pengetahuan petugas rekam medis 0-10. Kategori tingkat pengetahuan petugas rekam medis menggunakan rumus :

Sehingga didapat kategori:

$$
\begin{gathered}
\text { Interval }=\frac{\text { nilai tertinggi }- \text { nilai terendah }}{\text { kelas }} \\
I=\frac{10-0}{3} \\
I=3,33=3
\end{gathered}
$$

1. Baik, jika skor mendapatkan 7-10

2. Cukup, jika mendapatkan skor 4-6

3. Kurang, jika mendapatkan skor 0-3

Peneliti mengumpulkan data tentang sikap petugas rekam medis dengan menggunakan angket dengan jumlah pertanyaan sebanyak 10 item. Angket yang digunakan adalah angket tertutup, yaitu angket yang sudah dilengkapi dengan jawaban. Setiap item terdiri dari empat pilihan jawaban menurut skala Likert. Untuk jawaban sangat sesuai diberi dengan skor 4, jawaban sesuai diberi skor 3, jawaban tidak sesuai diberi skor 2 dan jawaban tidak sesuai diberi skor 1 .

Skor tertinggi adalah $40(10 \times 4)$ dan jawaban yang terendah 10(10x1) sehingga rentang skor untuk sikap petugas rekam medis 10-40. Kategori tingka sikap petugas menggunakan rumus :

$$
\begin{aligned}
\text { Interval } & =\frac{\text { nilai tertinggi }- \text { nilai terendah }}{\text { kelas }} \\
\mathrm{I} & =\frac{40-10}{3} \\
\mathrm{I} & =10
\end{aligned}
$$

Sehingga dapat dikategori :

1. Baik, jika skor mendapatkan 31-40

2. Cukup, jika mendapatkan skor 21-30

3. Kurang, jika mendapatkan skor 10-20

\section{F. Teknik Pengumpulan Data}

Cara pengumpulan data pada penelitian ini adalah metode angket. Angket adalah suatu cara pengumpulan data atau suatu penelitian mengenai suatu masalah yang umumnya banyak menyangkut kepentingan umum (banyak orang). Angket dilakukan dengan membagikan suatu daftar pertanyaan yang berupa formulir-formulie, 
diajukan secara tertulis kepada sejumlah subjek untuk mendapatkan tanggapan, informasi, jawaban, dan sebagainya (Notoadmojo, 2012).

G. Teknik Analisis Data

Data akan dianalisis dengan menggunakan statistik deskriptif yaitu teknik analisis data yang menggambarkan situasi objek penelitian ini dilakukan dengan bantuan komputer.

1. Analisis Univariat, dalam analisis univariat ini data dihitung untuk masing-masing variabel disajikan dalam tabel distribusi frekuensi.

2. Analisis Bivariat, untuk mengetahui hubungan keterlambatan klaim terhadap petugas klaim, kelengkapan dokumen rekam medis, sarana prasarana dan prosedur klaim. Peneliti menggunakan teknik analisis data yaitu uji Chi-Square $\left(X^{2}\right)$ menggunakan aplikasi pada komputer dengan tingkat kemaknaan 95\% $(\alpha=0,05)$, penerimaan atau penolakan hipotesis adalah sebagai berikut :

a. Ho diterima dan Ha ditolak jika nilai X2 hitung > X2 tabel atau nilai p>0,05 berarti tidak ada hubungan keterlambatan klaim terhadap petugas rekam medis, Informasi, sarana prasarana dan prosedur klaim.

b. Ho ditolak dan Ha diterima jika nilai X2 hitung $>X 2$ tabel atau nilai $p>0,05$ berarti ada hubungan keterlambatan klaim terhadap petugas rekam medis, Informasi, sarana prasarana dan prosedur klaim.

\section{HASIL DAN PEMBAHASAN}

\subsection{Hasil}

Dari hasil penelitian yang dilakukan peneliti mengenai ''Faktor-Faktor Penyebab Keterlambatan Klaim BPJS di Rumah Sakit Umum Imelda Pekerja Indonesia Medan Tahun 2020" dari 10 petugas klaim BPJS.

\section{Analisis Univariat}

Tabel 2. Distribusi Frekuensi Berdasarkan Umur Petugas Klaim di RSU IPI Medan.

\begin{tabular}{lccc}
\hline No. & Umur & Frekuensi & Persentase (\%) \\
\hline $\mathbf{1 .}$ & $21-30$ Tahun & 7 & 70 \\
\hline $\mathbf{2 .}$ & 31-40 Tahun & 3 & 30 \\
\hline & Total & $\mathbf{1 0}$ & $\mathbf{1 0 0}$
\end{tabular}

Berdasarkan tabel diatas dari 10 responden, mayoritas petugas klaim berumur 21-30 tahun sebanyak 7 orang $(70 \%)$ dan minioritas petugas klaim berumur 31-40 tahun sebanyak 3orang (30\%)

Tabel 3. Distribusi Frekuensi Berdasarkan Jenis Kelamin Petugas Klaim di RSU IPI Medan

\begin{tabular}{lccc}
\hline No. & Jenis Kelamin & Frekuensi & \multicolumn{2}{c}{ Persentase (\%) } \\
\hline 1. & Perempuan & 8 & 80 \\
\hline 2. & Laki-laki & 2 & 20 \\
\hline & Total & $\mathbf{1 0}$ & $\mathbf{1 0 0}$
\end{tabular}

Berdasarkan tabel diatas dari 10 petugas klaim, mayoritas petugas klaim berjenis kelamin perempuan sebanyak 8 orang $(80 \%)$ dan minioritas petugas klaim berjenis kelamin laki-laki sebanyak 2 orang (20\%). 
Tabel 4. Distribusi Frekuensi Berdasarkan Pendidikan Petugas Klaim di RSU IPI Medan

\begin{tabular}{lllc}
\hline No. & Pendidikan & Frekuensi & Persentase (\%) \\
\hline 1. & D3 RMIK & 5 & 50 \\
\hline 2. & S1 RMIK & 2 & 20 \\
\hline 3. & D3 Non RMIK & 3 & 30 \\
\hline & Total & $\mathbf{1 0}$ & $\mathbf{1 0 0}$ \\
\hline
\end{tabular}

Berdasarkan tabel diatas, mayoritas petugas klaim memiliki latar belakang Pendidikan D3 RMIK sebanyak 5 orang (50\%), Petugas dengan latar belakang pendidikan D3 Non RMIK sebanyak 3 orang (30\%) dan minioritas petugas memiliki latar belakang pendidikan S1 RMIK sebanyak 2 orang (20\%).

Tabel 5. Distribusi Frekuensi Berdasarkan Pengalaman Kerja Petugas Klaim di RSU IPI Medan

\begin{tabular}{llcc}
\hline No. & Pengalaman Kerja & Frekuensi & Persentase (\%) \\
\hline 1. & 0-1 Tahun & 4 & 40 \\
\hline 2. & 2-3 Tahun & 3 & 30 \\
\hline 3. & 4-5 Tahun & 2 & 20 \\
\hline 4. & >5 Tahun & 1 & 10 \\
\hline & Total & $\mathbf{1 0}$ & $\mathbf{1 0 0}$ \\
\hline
\end{tabular}

Berdasarkan tabel diatas menunjukan mayoritas pengalaman kerja petugas klaim yaitu 0-1 tahun sebanyak 4 orang $(40 \%)$ dan minioritas petugas memiliki pengalaman kerja sebanyak 1 orang $(10 \%)$.

Tabel 6. Distribusi Frekuensi Berdasarkan Pelatihan Petugas Klaim di RSU IPI Medan

\begin{tabular}{llcc}
\hline No. & Pelatihan & Frekuensi & Persentase (\%) \\
\hline 1. & Tidak ada & 6 & 60 \\
\hline 2. & Ada & 4 & 40 \\
\hline & Total & $\mathbf{1 0}$ & $\mathbf{1 0 0}$ \\
\hline
\end{tabular}

Berdasarkan tabel diatas mayoritas petugas klaim tidak ada ikut pelatihan sebanyak 6 orang $(60 \%)$ dan minioritas petugas memiliki pelatihan sebanyak 4 orang (40\%).

Tabel 7. Distribusi Frekuensi Berdasarkan Pengetahuan Petugas Klaim Di RSU IPI Medan

\begin{tabular}{llcc}
\hline No. & Pengetahuan & Frekuensi & Persentase (\%) \\
\hline 1. & Kurang & 6 & 60 \\
\hline 2. & Cukup & 0 & 0 \\
\hline 3. & Baik & 4 & \multicolumn{2}{c}{40} \\
\hline & Total & $\mathbf{1 0}$ & $\mathbf{1 0}$ \\
\hline
\end{tabular}

Berdasarkan tabel diatas mayoritas petugas klaim memiliki pengetahuan kurang terhadap klaim BPJS sebanyak 6 orang $(60 \%)$ dan minioritas petugas klaim memiliki pengetahuan baik terhadap klaim BPJS sebanyak 4 orang (40\%).

Tabel 8. Distribusi Frekuensi Berdasarkan Sikap Petugas Klaim di RSU IPI Medan

\begin{tabular}{llcc}
\hline No. & Sikap & Frekuensi & Persentase (\%) \\
\hline 1. & Kurang & 6 & 60 \\
\hline 2. & Cukup & 0 & 0 \\
\hline
\end{tabular}




\begin{tabular}{llcc}
\hline 3. & Baik & 4 & 40 \\
\hline & Total & $\mathbf{1 0}$ & $\mathbf{1 0}$ \\
\hline
\end{tabular}

Berdasarkan tabel diatas mayoritas petugas klaim memiliki sikap kurang terhadap klaim BPJS sebanyak 6 orang $(60 \%)$ dan minioritas petugas klaim memiliki sikap baik terhadap klaim BPJS sebanyak 4 orang (40\%).

Tabel 9. Distribusi Frekuensi Berdasarkan Informasi Kelengkapan Dokumen Rekam Medis di RSU IPI Medan

\begin{tabular}{llcc}
\hline No. & Informasi & Frekuensi & Persentase (\%) \\
\hline 1. & Lengkap & 4 & 40 \\
\hline 2. & Tidak Lengkap & 6 & 60 \\
\hline & Total & $\mathbf{1 0}$ & $\mathbf{1 0 0}$ \\
\hline
\end{tabular}

Berdasarkan tabel diatas menunjukan distribusi frekuensi informasi kelengkapan dokumen rekam medis terhadap klaim BPJS. Mayoritas informasi kelengkapan dokumen rekam medis tidak lengkap sebanyak 6 (60\%) dan minioritas lengkap sebanyak 4 (40\%).

Tabel 10. Distribusi Frekuensi Berdasarkan Sarana dan Prasarana di RSU IPI Medan

\begin{tabular}{llll}
\hline No. & Sarana dan Prasarana & Frekuensi & Persentase (\%) \\
\hline 1. & Lengkap & 4 & 40 \\
\hline 2. & Tidak Lengkap & 6 & 60 \\
\hline & Total & $\mathbf{1 0}$ & $\mathbf{1 0 0}$ \\
\hline
\end{tabular}

Berdasarkan tabel diatas menunjukan distribusi frekuensi sarana prasarana terhadap terhadap klaim BPJS. Sarana dan prasarna tidak lengkap sebanyak $6(60 \%)$ dan minioritas sarana prasarana lengkap sebanyak 4 (40\%).

Tabel 11. Distribusi Frekuensi Berdasarkan Prosedur Klaim di RSU IPI Medan

\begin{tabular}{llcc}
\hline No. & Prosedur Klaim & Frekuensi & Persentase (\%) \\
\hline 1. & Ada & 6 & 60 \\
\hline 2. & Tidak Ada & 4 & 40 \\
\hline & Total & $\mathbf{1 0}$ & $\mathbf{1 0 0}$
\end{tabular}

Berdasarkan tabel distribusi frekuensi diatas mayoritas ada prosedur klaim sebanyak 6 $(60 \%)$ dan minioritas tidak ada prosedur klaim sebanyak 4 (40\%).

Analisis Bivariat

Tabel 12. Hubungan Faktor Umur Petugas Klaim Dengan Keterlambatan Klaim di RSU IPI Medan

\begin{tabular}{|c|c|c|c|c|c|c|c|c|}
\hline \multirow[t]{3}{*}{ No } & \multirow[t]{3}{*}{ Umur } & \multicolumn{6}{|c|}{ Keterlambatan Klaim BPJS } & \multirow[t]{3}{*}{$\mathbf{P}$} \\
\hline & & \multicolumn{2}{|c|}{ Tidak Terlambat } & \multicolumn{2}{|c|}{ Terlambat } & \multicolumn{2}{|c|}{ Total } & \\
\hline & & $\mathbf{F}$ & $\%$ & $\mathbf{F}$ & $\%$ & $\mathbf{F}$ & $\%$ & \\
\hline 1 & 21-30 Tahun & 3 & 30 & 4 & 40 & 7 & 70 & 1 \\
\hline 2 & 31-40 Tahun & 1 & 10 & 2 & 20 & 3 & 30 & \\
\hline & Total & 4 & 40 & 6 & 60 & 10 & 100 & \\
\hline
\end{tabular}

Berdasarkan Tabel diatas menunjukan hasil uji stastistik tentang pengaruh umur petugas Klaim dengan keterlambatan klaim diperoleh $\mathrm{p}=1>0,05$ sehingga Ho diterima artinya tidak hubungan umur terhadap keterlambatan klaim. Mayoritas petugas dengan umur 21-30 tahun menyebabkan keterlambatan klaim sebanyak 4 responden (40\%). Dan minioritas petugas yang berumur 31-40 tahun tidak terjadi keterlambatan sebanyak 1 responden $(10 \%)$. 
Tabel 12. Hubungan Faktor Jenis Kelamin Petugas Klaim Dengan Keterlambatan Klaim di RSU IPI Medan

\begin{tabular}{|c|c|c|c|c|c|c|c|c|}
\hline \multirow{3}{*}{ No. } & \multirow{3}{*}{$\begin{array}{l}\text { Jenis } \\
\text { Kelamin }\end{array}$} & \multicolumn{6}{|c|}{ Keterlambatan Klaim BPJS } & \multirow{3}{*}{$\mathbf{P}$} \\
\hline & & \multicolumn{2}{|c|}{ Tidak Terlambat } & \multicolumn{2}{|c|}{ Terlambat } & \multicolumn{2}{|c|}{ Total } & \\
\hline & & $\mathbf{F}$ & $\%$ & $\mathbf{F}$ & $\%$ & $\mathbf{F}$ & $\%$ & \\
\hline 1. & Perempuan & 4 & 40 & 4 & 40 & 8 & 80 & 0,67 \\
\hline 2. & Laki-laki & 0 & 0 & 2 & 20 & 2 & 20 & \\
\hline \multicolumn{2}{|c|}{ Total } & 4 & 40 & 6 & 60 & 10 & 100 & \\
\hline
\end{tabular}

Berdasarkan tabel diatas menunjukan hasil uji stastistik tentang pengaruh jenis kelamin petugas rekam medis dengan keterlambatan klaim. Mayoritas Petugas klaim dengan jenis kelamin perempuan yang terlambat klaim sebanyak 4 responden $(40 \%)$. Sedangkan petugas dengan jenis kelamin laki laki yang terlambat klaim sebanyak 2 responden (20\%) Diperoleh $\mathrm{p}=0,67>0,05$ sehingga Ho diterima artinya tidak ada hubungan antara jenis kelamin petugas klaimdengan keterlambatan klaim di RSU IPI.

Tabel 13. Hubungan Pengetahuan Petugas Klaim Dengan Keterlambatan Klaim di RSU IPI Medan

\section{Keterlambatan Klaim BPJS}

\begin{tabular}{|c|c|c|c|c|c|c|c|}
\hline \multirow[t]{2}{*}{ No } & \multirow[t]{2}{*}{ Pengetahuan } & \multicolumn{2}{|c|}{ Tidak Terlambat } & \multicolumn{2}{|c|}{ Terlambat } & \multicolumn{2}{|c|}{ Total } \\
\hline & & $\mathbf{F}$ & $\%$ & $\mathbf{F}$ & $\%$ & $\mathbf{F}$ & $\%$ \\
\hline 1. & Kurang & 0 & 0 & 6 & 60 & 6 & 60 \\
\hline 2. & Cukup & 0 & 0 & 0 & 0 & 0 & 0 \\
\hline 3. & Baik & 4 & 40 & 0 & 0 & 40 & 40 \\
\hline & Total & 4 & 40 & 6 & 60 & 10 & 100 \\
\hline
\end{tabular}

Berdasarkan tabel diatas menunjukkan hasil uji statistik tentang pengaruh Pengetahuan petugas klaim dengan keterlambatan klaim BPJS rawat inap. Mayoritas Pengetahuan petugas klaim yang kurang menyebabkan keterlambatan sebanyak 6 (60\%). Minioritas Petugas klaim yang memiliki pengetahuan yang baik dan tidak terjadi keterlambatan klaim sebanyak 4 reponden (40\%). Diperoleh $\mathrm{p}=0,004<0,05$ sehingga Ho ditolak artinya ada hubungan antara pengetahuan petugas klaim dengan keterlambatan klaim BPJS rawat inap di RSU IPI Medan.

Tabel 14. Hubungan Faktor Pelatihan Petugas Klaim Dengan Keterlambatan Klaim di RSU IPI Medan

Keterlambatan Klaim BPJS

\begin{tabular}{|c|c|c|c|c|c|c|c|c|}
\hline \multirow[t]{2}{*}{ No. } & \multirow[t]{2}{*}{ Pelatihan } & \multicolumn{2}{|c|}{ Tidak Terlambat } & \multicolumn{2}{|c|}{ Terlambat } & \multicolumn{2}{|c|}{ Total } & \multirow[t]{2}{*}{$\mathbf{P}$} \\
\hline & & $\mathbf{F}$ & $\%$ & $\mathbf{F}$ & $\%$ & $\mathbf{F}$ & $\%$ & \\
\hline 1. & Ada Pelatihan & 3 & 30 & 1 & 10 & 4 & 40 & 1,90 \\
\hline 2. & Tidak ada Pelatihan & 1 & 10 & 5 & 50 & 6 & 60 & \\
\hline & Total & 4 & 40 & 6 & 60 & 10 & 100 & \\
\hline
\end{tabular}

Tabel diatas menunjukan hasil uji stastistik tentang pengaruh pelatihan petugas klaim dengan keterlambatan klaim. Mayoritas petugas yang tidak mengikuti pelatihan terjadi keterlambatan sebanyak 5 responden (50\%). Minioritas Petugas klaim yang mengikuti pelatihan tidak terjadi keterlambatan dalam klaim sebanyak 3 responden (30\%). Diperoleh $\mathrm{p}=1,90>0,05$ sehingga Ho diterima artinya tidak ada hubungan antara pelatihan petugas rekam medis dengan keterlambatan klaim di RSU IPI. 
Tabel 15. Hubungan Faktor Pendidikan Petugas Klaim Dengan Keterlambatan Klaim di RSU IPI Medan

\begin{tabular}{|c|c|c|c|c|c|c|c|c|}
\hline \multirow{3}{*}{ No. } & \multirow{3}{*}{ Pendidikan } & \multicolumn{6}{|c|}{ Keterlambatan Klaim BPJS } & \multirow{3}{*}{$\mathbf{P}$} \\
\hline & & \multicolumn{2}{|c|}{ Tidak Terlambat } & \multicolumn{2}{|c|}{ Terlambat } & \multicolumn{2}{|c|}{ Total } & \\
\hline & & $\mathbf{F}$ & $\%$ & $\mathbf{F}$ & $\%$ & $\mathbf{F}$ & $\%$ & \\
\hline 1 & D3 RMIK & 2 & 20 & 3 & 30 & 5 & 50 & \multirow[t]{4}{*}{1,19} \\
\hline 2 & S1 RMIK & 2 & 20 & 0 & 0 & 2 & 20 & \\
\hline 3 & D3 Non RMIK & 0 & 0 & 3 & 30 & 1 & 30 & \\
\hline & Total & 4 & 40 & 6 & 60 & $\overline{10}$ & 100 & \\
\hline
\end{tabular}

Berdasarkan Tabel diatas menunjukkan hasil uji statistik tentang pengaruh pendidikan petugas klaim dengan keterlambatan klaim BPJS rawat inap. Petugas klaim dengan latar belakang pendidikan D3 RMIK terjadi keterlambatan sebanyak 3 responden (30\%). S1 RMIK tidak terjadi keterlambatan sebanyak 2 responden (20\%). Petugas dengan latar belakng D3 Non RMIK terjadi keterlambatan klaim sebanyak 3 responden (30\%). Diperoleh $\mathrm{p}=1,19>0,05$ sehingga Ho diterima artinya tidak ada hubungan antara pendidikan petugas klaim dengan keterlambatan klaim BPJS rawat inap di RSU IPI Medan.

Tabel 16. Hubungan Pengalaman Kerja Petugas Klaim Dengan Keterlambatan Klaim di RSU IPI Medan

\begin{tabular}{|c|c|c|c|c|c|c|c|c|}
\hline \multirow{3}{*}{ No. } & \multirow{3}{*}{$\begin{array}{l}\text { Pengalaman } \\
\text { kerja }\end{array}$} & \multicolumn{6}{|c|}{ Keterlambatan Klaim BPJS } & \multirow{3}{*}{$\mathbf{P}$} \\
\hline & & \multicolumn{2}{|c|}{ Tidak Terlambat } & \multicolumn{2}{|c|}{ Terlambat } & \multicolumn{2}{|c|}{ Total } & \\
\hline & & $\mathbf{F}$ & $\%$ & $\mathbf{F}$ & $\%$ & $\mathbf{F}$ & $\%$ & \\
\hline 1. & 0-1 Tahun & 3 & 30 & 1 & 10 & 4 & 40 & \multirow[t]{5}{*}{0,629} \\
\hline 2. & 2-3 Tahun & 1 & 10 & 2 & 20 & 3 & 30 & \\
\hline 3. & 4-5 Tahun & 0 & 0 & 2 & 20 & 2 & 20 & \\
\hline 4. & $>5$ Tahun & 0 & 0 & 2 & 20 & 1 & 10 & \\
\hline & Total & 4 & 40 & 6 & 60 & 10 & 100 & \\
\hline
\end{tabular}

Berdasarkan tabel diatas menunjukkan hasil uji statistik tentang pengaruh Pengalaman kerja petugas klaim dengan keterlambatan klaim BPJS rawat inap. Diperoleh $\mathrm{p}=0,629>0,05$ sehingga Ho diterima artinya tidak ada hubungan antara Pengalaman kerja petugas klaim dengan keterlambatan klaim BPJS rawat inap di RSU IPI Medan.

Tabel 17. Hubungan Faktor Sikap Petugas Klaim Dengan Keterlambatan Klaim di RSU IPI Medan

\begin{tabular}{|c|c|c|c|c|c|c|c|c|}
\hline \multirow{3}{*}{ No. } & \multirow{3}{*}{ Sikap } & \multicolumn{6}{|c|}{ Keterlambatan Klaim BPJS } & \multirow{3}{*}{$\mathbf{P}$} \\
\hline & & \multicolumn{2}{|c|}{ Tidak Terlambat } & \multicolumn{2}{|c|}{ Terlambat } & \multicolumn{2}{|c|}{ Total } & \\
\hline & & $\mathbf{F}$ & $\%$ & $\mathbf{F}$ & $\%$ & $\mathbf{F}$ & $\%$ & \\
\hline 1. & Kurang & 0 & 0 & 6 & 60 & 6 & 60 & $\mathbf{0 , 0 4}$ \\
\hline 2. & Cukup & 0 & 0 & 0 & 0 & 0 & 0 & \\
\hline 3. & Baik & 4 & 40 & 0 & 0 & 4 & 40 & \\
\hline & Total & 4 & 40 & 6 & 60 & 10 & 100 & \\
\hline
\end{tabular}

Berdasarkan tabel diatas menunjukkan hasil uji statistik tentang pengaruh sikap petugas klaim dengan keterlambatan klaim BPJS rawat inap. Mayoritas Petugas klaim yang memiliki sikap yang kurang menyebabkan keterlambatan klaim sebanyak 6 reponden (60\%). Diperoleh $\mathrm{p}=0,004<0,05$ sehingga Ho ditolak artinya ada hubungan antara pengetahuan petugas klaim dengan keterlambatan klaim BPJS rawat inap di RSU IPI Medan.

Tabel 18. Hubungan Faktor Informasi Kelengkapan Dokumen Dengan Keterlambatan Klaim di RSU IPI Medan 


\begin{tabular}{|c|c|c|c|c|c|c|c|c|}
\hline \multirow{3}{*}{ No } & \multirow{3}{*}{$\begin{array}{l}\text { Informasi } \\
\text { Kelengkapan } \\
\text { Dokumen }\end{array}$} & \multicolumn{6}{|c|}{ Keterlambatan Klaim BPJS } & \multirow{3}{*}{$\mathbf{P}$} \\
\hline & & \multicolumn{2}{|c|}{ Tidak Terlambat } & \multicolumn{2}{|c|}{ Terlambat } & \multicolumn{2}{|c|}{ Total } & \\
\hline & & $\mathbf{F}$ & $\%$ & $\mathbf{F}$ & $\%$ & $\mathbf{F}$ & $\%$ & \\
\hline 1 & Lengkap & 4 & 40 & 0 & 0 & 4 & 40 & \multirow[t]{3}{*}{$\mathbf{0 , 0 4}$} \\
\hline \multirow[t]{2}{*}{2} & Tidak Lengkap & 0 & 0 & 6 & 60 & 6 & 60 & \\
\hline & Total & 4 & 40 & 6 & 60 & 10 & 100 & \\
\hline
\end{tabular}

Berdasarkan Tabel diatas menunjukkan hasil uji statistik tentang pengaruh kelengkapan dokumen rekam medis dengan keterlambatan klaim BPJS rawat inap. Dokumen yang lengkap tidak menyebabkan keterlambatan sebanyak 4 (40\%) sedangkan dokumen yang tidak lengkap menyebabkan keterlambatan klaim sebanyak 6 (60\%). Diperoleh $\mathrm{p}=0,004<0,05$ sehingga Ho ditolak artinya ada hubungan antara kelengkapan dokumen rekam medis dengan keterlambatan klaim BPJS rawat inap di RSU IPI Medan.

Tabel 19. Hubungan Faktor Sarana dan Prasarana Keterlambatan Klaim di RSU IPI Medan

\begin{tabular}{|c|c|c|c|c|c|c|c|c|}
\hline \multirow{3}{*}{ No } & \multirow{3}{*}{$\begin{array}{l}\text { Sarana dan } \\
\text { Prasarana }\end{array}$} & \multicolumn{6}{|c|}{ Keterlambatan Klaim BPJS } & \multirow{3}{*}{$\mathbf{P}$} \\
\hline & & \multicolumn{2}{|c|}{ Tidak Terlambat } & \multicolumn{2}{|c|}{ Terlambat } & \multicolumn{2}{|c|}{ Total } & \\
\hline & & $\mathbf{F}$ & $\%$ & $\mathbf{F}$ & $\%$ & $\mathbf{F}$ & $\%$ & \\
\hline 1 & Lengkap & 4 & 40 & 0 & 0 & 4 & 40 & \multirow[t]{3}{*}{0,04} \\
\hline 2 & Tidak Lengkap & 0 & 0 & 6 & 60 & 6 & 60 & \\
\hline & Total & 4 & 40 & 6 & 60 & 10 & 100 & \\
\hline
\end{tabular}

Berdasarkan tabel diatas menunjukkan hasil uji statistik tentang pengaruh sarana dan prasarana dengan keterlambatan klaim BPJS rawat inap. Mayoritas Sarana sarana prasarana yang tidak lengkap menyebabkan keterlambatan klaim sebanyak 6 (60\%). Minioritas Sarana prasarana yang lengkap tidak menyebabkan keterlambatan sebanyak 4 (40\%) Diperoleh $\mathrm{p}=0,004<0,05$ sehingga Ho ditolak artinya ada hubungan antara sarana dan prasarana dengan keterlambatan klaim BPJS rawat inap di RSU IPI Medan.

Tabel 20. Hubungan Faktor Prosedur Klaim Dengan Keterlambatan Klaim di RSU IPI Medan

\begin{tabular}{llccccccc}
\hline \multirow{2}{*}{ No. } & \multirow{2}{*}{$\begin{array}{l}\text { Prosedur } \\
\text { klaim }\end{array}$} & \multicolumn{6}{c}{ Keterlambatan Klaim BPJS } & \multirow{2}{*}{ P } \\
\cline { 2 - 8 } & & Tidak Terlambat & Terlambat & \multicolumn{2}{c}{ Total } & \\
\cline { 2 - 7 } 1. & Ada & 4 & 40 & 2 & 20 & 6 & 60 & $\mathbf{0 , 7 1}$ \\
\hline 2. & Tidak ada & 0 & 0 & 4 & 40 & 4 & 40 \\
\hline & Total & $\mathbf{4}$ & $\mathbf{4 0}$ & $\mathbf{6}$ & $\mathbf{6 0}$ & $\mathbf{1 0}$ & $\mathbf{1 0 0}$ & \\
\hline
\end{tabular}

Berdasarkan tabel diatas menunjukkan hasil uji statistik tentang pengaruh prosedur klaim dengan keterlambatan klaim BPJS rawat inap. Mayoritas prosedur klaim ada, tidak menyebabkan keterlambatan sebanyak 4 (40\%). Dan minioritas prosedur klaim tidak ada menyebabkan keterlambatan klaim. Diperoleh $\mathrm{p}=0,71>0,05$ sehingga Ho diterima artinya ada hubungan antara prosedur klaim Rekam medis dengan keterlambatan klaim BPJS rawat inap di RSU IPI Medan.

\subsection{Pembahasan}

\section{Hubungan Faktor Pengetahuan Petugas Rekam Medis Dengan Keterlambatan} Klaim BPJS di RSU IPI Medan

Pengetahuan merupakan hasil "tahu" dan ini terjadi setelah orang mengadakan penginderaan terhadap suatu objek tertentu (Wawan dan Dewi, 2011). Pada hasil penelitian berdasarkan distribusi pengetahuan petugas klaim dari 10 responden yang telah diteliti, 
petugas klaim yang berpengetahuan kurang lebih banyak dari petugas rekam medis yang berpengetahuan baik. Petugas rekam medis yang berpengetahuan kurang sebanyak 6 orang $(60 \%)$ dan petugas yang berpengetahuan baik sebanyak 4 orang (29\%). Diperoleh $\mathrm{p}=0,004<0,005$ sehingga Ho ditolak artinya ada hubungan pengetahuan petugas klaim dengan keterlambatan klaim BPJS rawat inap di RSU IPI. Jadi apabila pengetahuan rendah atau cukup maka pengklaiman akan tidak tepat waktu. Hasil penelitian ini sesuai dengan studi kasus yang telah dilakukan oleh Ayu Puspita Sari tahun 2012 di RSUP Dr. Kariadi Semarang bahwa hal yang berkaitan dengan keterlambatan satu diantaranya adalah tingkat pengetahuan. Sehingga petugas yang kurang memiliki pengetahuan maka pelaksanaan klaim biaya rawat inap peserta KJS akan terlambat.

\section{Hubungan Faktor Sikap Petugas Rekam Medis Dengan Keterlambatan Klaim BPJS di RSU IPI Medan}

Sikap merupakan evaluasi umum yang dibuat manusia terhadap dirinya sendiri,orang lain, objek atau isue. Sikap juga merupakan reaksi atau respon seseorang yang masih tertutup terhadap suatu stimulus atau objek (Wawan dan Dewi, 2010). Pada hasil penelitian berdasarkan distribusi pengetahuan petugas klaim dari 10 responden yang telah diteliti, petugas klaim yang memiliki sikap kurang lebih banyak dari petugas klaim yang memiliki sikap baik. Petugas klaim yang bersikap kurang sebanyak 6 orang $(60 \%)$ dan petugas yang bersikap baik sebanyak 4 orang (40\%). Diperoleh $\mathrm{p}=0,04<0,005$ sehingga Ho ditolak artinya ada hubungan sikap petugas klaim dengan keterlambatan klaim BPJS rawat inap di RSU IPI. Petugas dengan sikap kurang baik atau cuku akan memiliki peluang terlambat mengerjakan klaim dibandingkan dengan petugas dengan sikap baik. Jadi apabila sikap kurang baik maka keterlambatan klaim akan tidak tepat waktu. Hal ini sesuai dengan definisi keterlambatan bahwa keterlambatan merupakan perilaku hasil dari sikap organisasi tertentu seperti ketidakpuasan (Rosse, dkk dalam Koslowsky, 2000). Sehingga sikap petugas yang kurang baik maka pelaksanaan klaim biaya rawat inap peserta KJS akan terlambat.

\section{Hubungan Faktor Kelengkapan Dokumen Rekam Medis Dengan Keterlambatan Klaim BPJS di RSU IPI Medan}

Kelengkapan berkas rekam medis rawat inap sebagai salah satu persyaratan klaim BPJS akan berpengaruh terhadap ketepatan dalam pelaksanaan klaim. Dari hasil penelitian berdasarkan distribusi kelengkapan dokumen rekam medis dari 10 responden yang telah diteliti, dokumen rekam medis yang tidak lengkap lebih banyak dari dokumen rekam medis yang lengkap. Pada hasil penelitian dokumen rekam medis yang lengkap sebanyak 4 berkas $(40 \%)$, dan dokumen rekam medis yang tidak lengkap sebanyak 6 berkas (60\%). Sedangkan jika dilihat dari hubungan dokumen rekam medis terhadap keterlambatan klaim diperoleh $\mathrm{p}=0,04<0,05$ artinya Ho ditolak artinya ada hubungan antara kelengkapan dokumen rekam medis terhadap keterlambatan pengklaiman. Hasil penelitian ini sejalan dengan penelitian (Nia Lewiani, dkk, 2017) mengatakan Kelengkapan berkas dokumen menjadi bagian penting dalam proses klaim. Apabila pihak rumah sakit dapat memenuhi kelengkapan dokumen, maka kemungkinan semakin cepat proses penggantian biaya pelayanan kesehatan yang telah diberikan.

\section{Hubungan Faktor Sarana dan Prasarana Dengan Keterlambatan Klaim BPJS di RSU IPI Medan}

Sarana prasarana adalah sesuatu yang digunakan dalam pencapaian maksud dari tujuan. Sedangkan prasarana adalah suatu faktor yang merupakan faktor penunjang terlaksanya suatu kegiatan. Dari hasil penelitian berdasarkan distribusi Sarana prasarana dari 10 responden yang telah diteliti, sarana prasarana yang lengkap sebanyak $4 \mathrm{~s} \mathrm{(40 \% ),}$ 
dan sarana prasarana yang tidak lengkap sebanyak $6(60 \%)$. Sedangkan jika dilihat dari sarana prasarana terhadap keterlambatan klaim diperoleh $\mathrm{p}=0,004<0,05$ artinya Ho ditolak artinya ada hubungan antara sarana prasarana terhadap keterlambatan pengklaiman.

\section{KESIMPULAN}

Berdasarkan hasil uji statistik yang dilakukan dengan menggunakan aplikasi komputer uji Chi Square $\left(\mathrm{X}^{2}\right)$ dengan kemaknaan $95 \%(\mathrm{p}<0,05)$ dapat disimpulkan :

1. Adanya hubungan Pengetahuan petugas terhadap keterlambatan klaim. Mayoritas petugas memiliki pengetahuan kurang terhadap klaim BPJS sebanyak 6 orang $(60 \%)$ dan minioritas petugas memiliki pengetahuan baik sebanyak 4 orang (40\%).

2. Adanya hubungan sikap petugas terhadap keterlambatan klaim. Mayoritas petugas memiliki sikap kurang terhadap klaim BPJS sebanyak 6 orang $(60 \%)$ dan minioritas petugas memiliki sikap baik sebanyak 4 orang (40\%).

3. Tidak ada hubungan antara umur petugas rekam medis dengan keterlambatan klaim BPJS Rawat inap di RSU IPI Medan. Hasil uji statistik diperoleh $p=1>0,05$.

4. Tidak ada hubungan antara jenis kelamin petugas rekam medis dengan keterlambatan klaim BPJS Rawat inap di RSU IPI Medan. Hasil uji statistik diperoleh $\mathrm{p}=0,667>0,05$.

5. Tidak ada hubungan pelatihan petugas rekam medis dengan keterlambatan klaim BPJS Rawat inap di RSU IPI Medan.

6. Tidak ada hubungan pendidikan petugas rekam medis dengan keterlambatan klaim BPJS Rawat inap di RSU IPI Medan.

7. Tidak ada hubungan antara pengalaman kerja petugas rekam medis dengan keterlambatan klaim BPJS Rawat inap di RSU IPI Medan.

8. Ada hubungan informasi kelengkapan dokumen rekam medis dengan keterlambatan klaim BPJS Rawat inap di RSU IPI Medan. Dari 10 responden sebanyak 6 (60\%) responden mengatakan kelengkapan informasi yang tidak lengkap menyebabkan keterlambatan dalam klaim kepada BPJS.

9. Ada hubungan Sarana Prasarana dengan keterlambatan klaim BPJS Rawat inap di RSU IPI Medan. Hasil uji statistik diperoleh $\mathrm{p}=0,04<0,05$. Dari 10 responden sebanyak $6(60 \%)$ mengatakan sarana prasarana yang tidak lengkap menyebabkan keterlambatan klaim kepada BPJS.

10. Tidak ada hubungan prosedur klaim dengan keterlambatan klaim BPJS Rawat inap di RSU IPI Medan. Hasil uji statistik diperoleh $p=0,76>0,05$.

\section{REFERENCES}

Anonim. Administrasi Klaim BPJS. http://www.Bpjs-kesehatan.go.id/. Diakses Pada: Juli 2020.

Dirjen YanMed. 2006. Pedoman Pengelolaan Rekam Medis Rumah Sakit di Indonesia. Jakarta: Dep Kes.

Ilyas, Yaslis. 2003. Mengenal Asuransi Kesehatan. Review Utilisasi, Manajemen Klaim, dan Fraud (Kecurangan Asuransi Kesehatan). Depok: Fakultas Kesehatan Masyarakat, Universitas Indonesia.

Leonard, Devid. 2016. Pengorganisasian Klaim Pelayanan Pasien JKN di RSUP M DR. M. Djamil Padang, Menara Ilmu. 
Nia Lewiani, Lisnawaty, Akifah, 2017. Proses Pengelolaan Klaim Pasien BPJS Unit Rawat Inap Rumah Sakit Dr. R. Ismoyo Kota Kendari Tahun 2016. https://media.neliti.com/media/publications/198035-proses-pengelolaan-klaim-pasienbpjs-uni.pdf diakses juli 2020.

Notoadmojo, 2012. Metodologi Penelitian Kesehatan. Jakarta : Rineka Cipta.

Pamungkas, Fantri. 2013. Analisis Ketidaklengkapan Pengisian Catatan Medis Berkas Rekam Medis di RSU PKU Muhamadiyah Yogyakarta, UGM. Yogyakarta 2013.

Permenkes No. 269/Menkes/III/2008 Tentang Rekam Medis.

Permenkes No. 71 Tahun 2013 Tentang Pelayanan Kesehatan Pada Jaminan Kesehatan Nasional. http://www.depkes.go.id//download/general/PMK.

Pury Feriawati, Agus Perry. 2015. Faktor-faktor Keterlambatan Penggklaiman BPJS Rawat Inap di Rumah Sakit Bayangkara, Semarang. http://eprints.dinus.ac.id/17499/1/jurnal_16477.pdf diakses pada Juli 2020.

Puspita Sari, Ayu, 2012. Hubungan Pengetahuan, Sikap Dan Perilaku Petugas Terhadap Keterlambatan Klaim Biaya Rawat Inap Peserta Kartu Jakarta Sehat (KJS) di RS Jiwa Dr. Soeharto Heerdjan. http.journal.uinalauddin.ac.id/index.php/join/article/ diakses pada Juli 2020.

Rustiyanto, Ery, 2009. Etika Profesi Perekam Medis dan Informasi Kesehatan Yogyakarta: Graha Ilmu.

Saryono dan Anggeraini. 2013. Metodologi Penelitian Kualitatif dan Kuantitatif Dalam Bidang Kesehatan. Yogyakarta: Nuha Medika.

Sophia, Ede Surya. 2016. Analisis Keterlambatan Pengajuan Klaim Badan Penyelenggara Jaminan Sosial (BPJS) Kesehatan pada Rumkital Dr. Mintohardjo, DKI Jakarta. http://dxdoi.org/10.22435/hsr.v20i3.6231.83-88diakses pada Juli 2020.

Sugiyono. (2007). Statistik Untuk Penelitian. Bandung: Alfabeta.

Undang-Undang Republik Indonesia No.24 Tahun 2011 tentang Badan Penyelenggara Jaminan Sosial. http.mewarisgagasan.wordpress.com.

Undang-Undang Republik Indonesia No. 40 Tahun 2004 Tentang Sistem Jaminan Sosial Nasional.

Undang-Undang Republik Indonesia Nomor 36 Tahun 2009 Tentang Kesehatan. http://binfar.depkes.go.id/dat/lama/1303887905_UU\%20362009\%20Kesehatan.pdf. Diakses pada Juli 2020.

Undang-Undang No. 44 Tahun 2009. Tentang Rumah Sakit. https://dinkes.bantenprov.go.id/read/undang-undang. Diakes pada Juni 2020.

Wawan dan Dewi. 2010. Pengetahuan, Sikap dan perilaku Manusia. Yogyakarta: Nuha Medika. 


\section{BIOGRAPHIES OF AUTHORS}

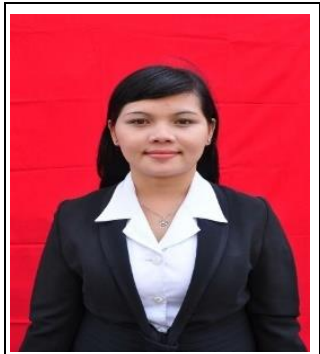

Erlindai, Gelar Sarjana diperoleh dari STIKes Deli Husada Deli Tua, Jurusan Ilmu Keseharan Masyarakat pada Tahun 2013. Magister Kesehatan Masyarakat diperoleh dari STIKes Deli Husada Deli Tua pada Tahun 2015. Saat ini aktif sebagai pengajar di Program Studi D-III Perekam dan Informasi Kesehatan Universitas Imelda Medan. 